\title{
Household Location AND RACE: A TWenty-YeAR RETROSPECTIVE
}

\section{Stuart A. Gabriel and Gary D. Painter*}

\begin{abstract}
In a paper published in The Review of Economics and Statistics some 20 years ago, we sought to assess the disparate residential location choices of black and white households in the Washington, D.C. metropolitan area (Gabriel and Rosenthal [1989]). The paper showed that simulated closure of large socio-economic gaps between blacks and whites did little to diminish prevailing high levels of residential segregation or otherwise enhance moves by black households to areas of educational, employment, and housing opportunity. In the wake of intervening decades, the current paper applies data from 2000 to assess anew racial variations in residential location choice. Results of the multinomial logit analysis indicate large, persistent racial differentials in residential location choice. While black location choice in 2000 was relatively more dispersed than in 1980, it remained remarkably concentrated in DC and Prince Georges County. As in our prior analysis, results showed that large simulated gains in black economic and educational status had little effect on prevailing racial segregation. These findings underscore the ongoing, limited access of black households to schooling, employment, and housing opportunities available outside traditional areas of settlement. In marked contrast, the locational choices of Latino and immigrant households bore greater similarity to those of whites and were more sensitive to improvements in socio-economic status.
\end{abstract}

JEL Classification: R19 


\section{Introduction}

About twenty years ago, we published a paper in The Review of Economics and Statistics that elucidated the damped suburbanization propensities of black households (Gabriel and Rosenthal [1989]). The starkly lower rates of minority suburbanization served to reinforce longstanding racial segregation in urban housing markets, (see, for example, Kain [1984], Streitweiser and Goodman [1983]). The lower rate of suburban moves by blacks adversely affected not only their housing consumption, but also their employment and educational opportunities (see, for example Kain [1968], Galster [1987], and Holzer [1991]).

Our earlier analysis was undertaken via estimation and simulation of a multinomial logit model of household location choice. The paper sought to distinguish among competing hypotheses regarding persistent urban racial segregation of white and minority households. Specifically, segregation outcomes could arise from some combination of socio-economic, racial bias, and preference-related factors. The prior paper sought to assess the extent to which intrametropolitan directional moves by black and white households were predicated on socioeconomic or other factors. ${ }^{1} \quad$ Model simulation evaluated whether elevation of black socioeconomic status would help to (a) alleviate racial segregation in housing and (b) foster black moves to areas of employment and housing opportunity.

Our analyses focused on the Washington, DC metropolitan area. Data for 1975-80 indicated that the vast majority of black intra-metropolitan moves were to DC or Prince Georges County. Indeed, unlike whites, relatively few black moves were evidenced to other ring suburbs of Maryland and Virginia. Model simulation indicated that even full closure of large gaps in socio-economic status between blacks and whites would do little to change the prevailing racial pattern of intra-urban moves. Indeed, research findings suggested that educational, job training 
or other policies aimed at raising black socio-economic status would be insufficient to encourage black suburbanization or to alleviate housing market racial segregation.

The intervening decades witnessed elevated rates of job growth among many Capitol Beltway communities. ${ }^{2}$ Further, the public school systems in Fairfax and Montgomery Counties remained dominant in the metro area and among the best in the nation. Accordingly, limited residential mobility likely translated into damped economic mobility. Indeed, some two decades later, low rates of movement by black households to growth areas outside the District of Columbia likely adversely affect their housing, schooling, and job opportunities (see, for example, Orfield and Lee [2005]; Boustan and Margo [2009]).

In this paper, we replicate our earlier analysis using PUMS data for the year 2000. While the intra-metropolitan residential location choices of Latino and immigrant movers came to more closely resemble those of whites, the pattern of black household moves remained much the same. Two decades later, 67 rather than 85 percent of black households chose to locate in DC and Prince Georges County. Further, simulated closure of large gaps in socio-economic status between blacks and whites did little to affect that pattern. In contrast, immigrant and Latino settlement patterns were more diverse than that of African-Americans. Further, moves by those groups to Montgomery and Fairfax Counties were substantially more sensitive to simulated elevation in socio-economic status.

\section{Data and Analysis}

As in our prior paper, we applied a multinomial logit (MNL) model to assess household location choice in the Washington, D.C. metro area. However, the residential choice set was expanded beyond the 5 original locations (Washington, D.C., Prince Georges, Montgomery, 
Arlington, and Fairfax Counties) to account for rapid growth over intervening years in Alexandria and Prince William County. ${ }^{3}$ Additionally, analyses were stratified among white, black, Latino, and immigrant households. As discussed in Painter and Yu [2008; 2010], recent decades have witnessed substantial migration of Latino and immigrant groups to and within Washington D.C. and other large U.S. cities.

The data set used to estimate the model was the PUMS 2000 Washington, D.C. metropolitan area file. The data included detailed information on the socioeconomic and demographic characteristics of survey respondents. The sample was comprised of households who moved into their homes during the 1995-2000 period. The estimation sample consisted of 31,474, of which 8327 were African Americans, 2629 were Latinos, and 5798 were immigrants. Explanatory variables included a full set of household economic, demographic, and other characteristics.

Household income was represented by controls for wage income and wage income squared, investment income, and other income. The latter term includes transfer payments and the like. ${ }^{4}$ In addition, a variety of categorical demographic variables were included in the analysis. The AGE variables included controls for household heads between 25-34, 35-44, 4554, and 55-64, with 18-24 as the omitted category. We also specify controls for single male head and single female head with married as the omitted category. The number of children under 18 living at home is represented by a continuous variable (number of kids), which reflects in part family concerns about the quality of local public schools. Prior research (Apgar and Pollakowski [1986], Pollakowski and Edwards [1987], Gabriel and Painter [2003, 2009] has indicated that household location choice varies importantly over the life cycle, as proxied by household marital status, age, and the presence of children. 
Also included are categorical variables for educational attainment, including less than high school and high school diploma, with collage and above as the omitted category. Household demands for differentiated baskets of local public goods (e.g., public schools, access to employment, and other locational amenities) are proxied in part by household educational attainment. The model also controls for homeowner tenure status.

Conditioned on socio-economic status, household race may importantly affect residential location choice due either to systematic differences among racial groups in preferences for neighborhood attributes or to the presence of racial bias or discrimination. Our prior analyses (Gabriel and Rosenthal [1989], Gabriel and Painter [2003, 2009]) revealed significant racial differences in the affects of household characteristics on intra-metropolitan residential location choice. In the below analysis, we test for coefficient stability across white, black, Latino, and immigrant samples.

Finally, our analysis controls for immigrant status and related date of migration to the U.S. As indicated below, recent decades have witnessed the migration of substantial immigrant populations to U.S. gateway cities. Immigrants tend to reside in communities of like population, often in center and inner-ring areas, and then disperse to outlying areas only with some lag from arrival date. In the below analysis, we seek to identify the timeframe and intrametropolitan destinations of immigrant moves (Painter et al, 2001).

Table 1 presents the means of the independent variables for the white, black, Latino, and immigrant subsamples. As is evident, there exist systematic differences in mover origins among the different groups. Among all groups, few metropolitan movers emanate from outlying Frederick, Prince William, or Loudon Counties. Among Whites, Latinos, and immigrants, sizable mover shares originate from Fairfax County. ${ }^{5}$ Most black movers come from Prince 
Georges and Montgomery Counties, whereas relatively few derive from the Virginia suburbs. In the empirical analysis, we control for mover origin location in determination of intrametropolitan location choice. Those fixed effects proxy for origin-specific attributes, including population socio-economic and racial characteristics, access to employment, quality of local public schools, and the like. ${ }^{6}$

The table further indicates that sampled white movers were characterized by much higher levels of wage income, educational attainment, and homeownership status, relative to their minority and immigrant counterparts. ${ }^{7}$ While the age profile of movers appears roughly similar across groups, Latino households were characterized by a higher proportion of younger movers in the 25-44 age group. Number of children was especially elevated among Latino and immigrant movers, relative to their white and black counterparts. Also, at about 45 percent, the proportion single female-headed mover households was especially elevated among blacks.

\section{Estimation Results}

Results of estimation of the unified MNL model of household location choice are contained in Appendix Table 1. As indicated, the estimated MNL coefficients reflect the effect of population socio-economic and locational controls on the likelihood of moving to location $j$ relative to DC. As evidenced in Appendix Table 1, there exists substantial variability in the role of socioeconomic and demographic characteristics in choice of Washington, D.C. residential location. Further, all things equal, the analyses reveal the importance of race to household location choice. While black household status is associated with statistically elevated propensities to move to Prince Georges County, statistically depressed likelihoods are associated with moves by black households to all other places. Latino households similarly demonstrate a 
statistically elevated propensity to move to Prince Georges County. In marked contrast, Asian and immigrant households statistically avoid moves to Prince Georges County and instead favor other areas.

\section{Model Simulation}

Given model estimates, we sought to quantitatively evaluate the extent to which elevation in minority household socio-economic status would (a) alleviate racial segregation in housing, and (b) increase movement of minority households to areas of economic and housing opportunity beyond the urban core. To explore these questions, two simulations were conducted. ${ }^{8}$ In the first exercise, the probability shares for each white household were calculated based on individual characteristics of white households and MNL coefficients for black, Latino, and immigrant groups. Because the MNL coefficients of minority and immigrant households embody the locational preferences and constraints pertinent to those groups, this exercise simulates the effect of raising the socioeconomic status of minorities and immigrants to that of whites. In a second simulation, probability shares were calculated based on the white MNL coefficients and the black household data. This simulation shows how black household location choice would be affected to the extent the group in question had similar housing preferences and opportunities to that of whites.

Simulation results for white and black households are presented in table 2. The table contains results from our current and prior (Gabriel and Rosenthal [1989]) analyses to enable comparison over intervening decades. In Table 2, note that in 1980, intra-metropolitan moves by black households were highly skewed in the direction of DC and Prince Georges County. The two destinations comprised a full 85 percent of black moves; only about 5 percent of black 
movers chose to locate in Montgomery, Fairfax, or Arlington Counties, respectively. Further, in 1980, large simulated improvements in black socio-economic status had little impact on black location choice. Specifically, the simulated elevation of black socio-economic status to that of whites reduced only slightly to 75 percent the proportion of black movers choosing to locate in DC or Prince Georges County.

Results for 2000 indicated that, despite some dispersion, the intra-metropolitan location choices of black households remained concentrated in DC and Prince Georges County. Indeed, black movers choosing to locate in DC or Prince Georges County declined from 85 percent in 1980 to about 66 percent in 2000 . The intervening decades did witness a substantial jump, from 6 percent in 1980 to 14 percent in 2000, in the share of black movers choosing to locate in Montgomery County. In marked contrast, moves by blacks to Fairfax County showed only limited increase over the intervening two decades. As in our prior study, large simulated increases in black socio-economic status to that of whites served to raise only slightly the share of black households choosing to locate in Montgomery and Fairfax Counties. Moreover, the simulated black intra-metropolitan location pattern differed markedly from that of white households. Relative to their simulated black socioeconomic counterparts, 2000 white household location choice was substantially more concentrated in the suburbs, notably Fairfax and Montgomery Counties, and evidenced to a far lesser degree in D.C. and Prince Georges County. Our findings suggest that DC area blacks made limited progress in movement beyond traditional areas of settlement over the intervening two decades. As previously, simulated elevation of black socioeconomic status to that of whites was inadequate to encourage levels of black movement to outlying areas commensurate with that of whites. Further, to a significant degree, patterns of black-white housing segregation evidenced in 1980 continued to prevail in 2000. 
It is clear from table 2 that the converse of the above conclusion also holds. When black households, with their existing socioeconomic characteristics, take on the locational preferences and constraints of white households (as embodied in the white MNL coefficient vector), the predicted pattern of black residential location is quite different from their actual location choices in the Washington, D.C. area. In contradistinction to results above, the locational choices of black households are skewed away from the traditional black residential choices and are instead heavily concentrated in Fairfax and Montgomery Counties. ${ }^{9} \quad$ Also, in contrast to findings of our prior study, results suggest that white location patterns are substantially insensitive to changes in socioeconomic status. Indeed, substitution of black socioeconomic characteristics for those of whites does little to change the intra-metropolitan distribution of white movers.

Table 3 characterizes the intra-metropolitan location choices for Latino and immigrant households for 2000 only, reflecting the expansion of the analysis to those groups for the more recent period. Interestingly, results for Latino and immigrant households reveal patterns of residential location starkly different from black households and more similar to those of white households. Fairfax and Montgomery Counties together comprise 51 and 59 percent of residential location choices among Latinos and immigrants, respectively. Similarly, both groups reveal relatively damped propensities to locate in DC or the inner-ring suburbs of Arlington and Alexandria. Upon elevation of the socioeconomic status of Latinos and immigrants to that of whites, those groups move away from Prince Georges and towards Montgomery and Fairfax counties. Note, however, the immigrant moves to DC rise modestly when incomes increase. ${ }^{10}$ 


\section{Conclusion}

Research findings indicate only limited dispersal over recent decades in choice of residential location among black households in the Washington, D.C. metro area. As in our earlier analysis (Gabriel and Rosenthal [1989]), intra-metropolitan location choice among blacks is relatively insensitive to simulated elevation in socio-economic status. In marked contrast, locational choices by Latino and immigrant households appear substantially closer to those of whites. Further, unlike their black socio-economic counterparts, Latinos and immigrants move to Fairfax County as their incomes increase. Findings point to the important role of race-based preferences and constraints in determination of intra-metropolitan location choice. They also indicate that gains in black economic and educational status do not necessarily imply black integration of previously highly segregated areas. These findings further underscore the persistent, limited access of black households to economic, educational, and housing opportunities available outside traditional areas of urban settlement. 


\section{FOOTNOTES}

*The authors are grateful to Cathy Liu and Keith Naughton for excellent research assistance. Gabriel is Arden Realty Chair and Professor of Finance, UCLA Anderson School of Management, 110 Westwood Plaza, Suite C412, Los Angeles, CA 90045-1481; email: sgabriel@anderson.ucla.edu. Painter is Associate Professor, School of Policy, Planning, and Development, University of Southern California, Los Angeles, CA 90089-1421; email: gpainter@sppd.usc.edu.

February 2, 2011

${ }^{1}$ We allowed here both for racial variation in estimated socio-economic coefficient vectors as well as for racial differences in the level of those terms.

${ }^{2}$ Recent decades have witnessed the creation of major sub-regional employment centers in Tysons Corner, the Dulles Corridor, Reston, the I-270 corridor, and other outlying areas.

${ }^{3}$ The probability of choosing location $j$ is given by $P_{j}=\exp \left(X^{\prime} \beta_{j}\right) D, j=1,2, \ldots, m-1$ and $P_{m}=$ $1 j D$ where $D=1+\sum j=1$ through $m-1 \exp \left(X^{\prime} \beta_{j}\right),(\mathrm{j}=1,2, \ldots, m)$ are the different alternatives, $P_{j}$ is the probability of choosing location $j, X$ is a vector of characteristics, and $\beta j$ is the vector of coefficients pertaining to location $j$. As with the simple bivariate logit model, the coefficients of the MNL are estimated only up to a scale factor, while the coefficients for the reference choice $\left(\beta_{\mathrm{m}}\right)$ are set equal to zero. The MNL model is attractive because the probability function is of a 
simple form and is strictly concave; hence, the $\beta$ vector has a unique solution which is easily estimable using standard maximum likelihood techniques.

${ }^{4}$ In a simple monocentric bid-rent model of urban spatial structure, higher-income households demanding more housing services will tend to locate in outlying areas; alternatively, when such a model is modified to account for commuting time, higher income households with a higher value of time may exhibit a greater preference to live in the central city. A priori, it is not clear what sign the income coefficients will take or how those effects will vary across race, ethnicity, and immigrant status.

${ }^{5}$ Similarly, large portions of those movers derive from outside the D.C. area.

${ }^{6}$ As regards broad characterization of study locations, note that substantially elevated shares of the D.C. and Prince Georges County populations are comprised of black households, whereas high proportions of white households are evidenced in Fairfax, Montgomery, and outlying counties. Elevated shares of immigrant population are evidenced in D.C., inner-ring suburbs of Arlington and Alexandria, and Fairfax County. In contrast, Latino population shares in the DC area are small and widely disbursed. Further, some two-thirds or more of the households in Fairfax, Montgomery, Arlington, and Alexandria had attained a college degree; in marked contrast, less than 40 percent of Prince Georges County households were college graduates. About one-third of the households in Prince Georges, Arlington, and Alexandria were headed by females, relative to about one-fifth in other areas. As would be anticipated, the District of Columbia was dominated by black, lower-income, single-headed households, and renters 
(although there exists large enclaves of white, higher-income owner-occupiers in the northwest quadrant of the District). Whereas Arlington County has a significant concentration of white, single, and educated families who rent, Prince Georges County is more heavily represented by black, middle-income, married families with children, and owner-occupiers. Fairfax County and Montgomery County are both characterized by high concentrations of white, higher-income, married, owner-and educated families with children.

${ }^{7}$ Further, while some level of investment income is evidenced for white movers, little investment income is apparent for the other groups.

${ }^{8}$ To conduct these simulations, a set of stratified multinomial models were estimated. These results are available upon request. We have omitted them here due to space constraints.

${ }^{9}$ A comparison with earlier findings does reveal some evolution in the distribution of white household moves over the past few decades. As shown in table 2, relative to 1980 , substantially lower proportions of white movers chose the District of Columbia or inner-ring suburbs of Arlington and Prince Georges Counties. Instead, mover shares to Montgomery County increased markedly, and a full 10 percent of recent white movers chose the outer-ring Prince William County. Notably, over the course of the two decades, the proportion of white movers choosing Fairfax County remained about constant at one-third.

${ }^{10}$ This is likely due to non-Latino immigrants moving to DC. 


\begin{tabular}{|c|c|c|c|c|}
\hline \multirow{2}{*}{ Racial/Ethnic Group } & White & Black & Latino & Immigrant \\
\hline & Mean & Mean & Mean & Mean \\
\hline Moved from - District of Columbia & 0.064 & 0.271 & 0.107 & 0.092 \\
\hline Frederick County & 0.038 & 0.007 & 0.006 & 0.005 \\
\hline Prince George's County & 0.137 & 0.104 & 0.183 & 0.214 \\
\hline Montgomery County & 0.040 & 0.279 & 0.094 & 0.106 \\
\hline Arlington County & 0.045 & 0.016 & 0.087 & 0.067 \\
\hline Alexandria County & 0.030 & 0.028 & 0.047 & 0.043 \\
\hline Fairfax County & 0.174 & 0.068 & 0.182 & 0.215 \\
\hline Prince William County & 0.049 & 0.031 & 0.042 & 0.026 \\
\hline Loudon County & 0.043 & 0.009 & 0.012 & 0.014 \\
\hline Other parts of the US & 0.379 & 0.187 & 0.240 & 0.220 \\
\hline Education - Less than high school & 0.031 & 0.122 & 0.396 & 0.228 \\
\hline High school diploma & 0.270 & 0.525 & 0.334 & 0.292 \\
\hline College & 0.699 & 0.353 & 0.270 & 0.481 \\
\hline Age Cohort - $\quad 18-24$ & 0.079 & 0.074 & 0.101 & 0.053 \\
\hline $25-34$ & 0.347 & 0.320 & 0.398 & 0.335 \\
\hline $35-44$ & 0.314 & 0.332 & 0.314 & 0.358 \\
\hline $45-54$ & 0.183 & 0.196 & 0.143 & 0.184 \\
\hline $55-64$ & 0.078 & 0.079 & 0.044 & 0.070 \\
\hline Marital Status -Single male head & 0.231 & 0.210 & 0.199 & 0.186 \\
\hline Single female head & 0.269 & 0.458 & 0.212 & 0.207 \\
\hline Married & 0.500 & 0.332 & 0.589 & 0.607 \\
\hline Number of Children & 0.647 & 0.935 & 1.274 & 1.065 \\
\hline Wage Income & 80.07 & 48.39 & 55.21 & 60.81 \\
\hline Wage Income squared & 11100 & 4114 & 5493 & 6713 \\
\hline Investment Income & 4.402 & 0.803 & 1.002 & 1.693 \\
\hline Other Income & 7.407 & 4.213 & 4.210 & 5.696 \\
\hline Homeowner & 0.550 & 0.370 & 0.374 & 0.437 \\
\hline
\end{tabular}


Table 2. Simulated Probability Shares of Household Location in the Washington D. C. Metropolitan Area

\begin{tabular}{|c|c|c|c|c|c|c|c|c|}
\hline & \multicolumn{4}{|c|}{ Black } & \multicolumn{4}{|c|}{ White } \\
\hline & \multicolumn{2}{|c|}{1981} & \multicolumn{2}{|c|}{2000} & \multicolumn{2}{|c|}{1981} & \multicolumn{2}{|c|}{2000} \\
\hline & $\begin{array}{c}\text { Actu } \\
\text { al }\end{array}$ & $\begin{array}{c}\text { Simulate } \\
\mathrm{d}\end{array}$ & $\begin{array}{c}\text { Actu } \\
\text { al }\end{array}$ & $\begin{array}{c}\text { Simulate } \\
\mathrm{d}\end{array}$ & $\begin{array}{c}\text { Actu } \\
\text { al }\end{array}$ & $\begin{array}{c}\text { Simulate } \\
\mathrm{d}\end{array}$ & $\begin{array}{c}\text { Actu } \\
\text { al }\end{array}$ & $\begin{array}{c}\text { Simulate } \\
\mathrm{d}\end{array}$ \\
\hline D.C. & 0.64 & 0.54 & 0.28 & 0.23 & 0.23 & 0.15 & 0.13 & 0.09 \\
\hline Montgomery & & & & & & & & \\
\hline County & 0.06 & 0.11 & 0.14 & 0.16 & 0.18 & 0.14 & 0.24 & 0.24 \\
\hline Prince George's & & & & & & & & \\
\hline County & 0.21 & 0.24 & 0.37 & 0.41 & 0.12 & 0.13 & 0.07 & 0.10 \\
\hline Arlington County & 0.04 & 0.03 & 0.02 & 0.02 & 0.13 & 0.10 & 0.09 & 0.06 \\
\hline Fairfax County & 0.05 & 0.08 & 0.09 & 0.10 & 0.34 & 0.48 & 0.30 & 0.32 \\
\hline Alexandria County & & & 0.04 & 0.03 & & & 0.07 & 0.04 \\
\hline Prince William & & & & & & & & \\
\hline County & & & 0.06 & 0.05 & & & 0.10 & 0.14 \\
\hline
\end{tabular}

Table 3. Simulated Probability Shares of Household Location in the Washington D. C. Metropolitan Area, 2000

\begin{tabular}{|c|c|c|c|c|}
\hline & \multicolumn{2}{|c|}{ Latino } & \multicolumn{2}{|c|}{ Immigrant } \\
\hline & Actual & Simulated & Actual & Simulated \\
\hline $\begin{array}{l}\text { D.C. } \\
\text { Montgomery }\end{array}$ & 12.72 & 10.06 & 10.01 & 11.03 \\
\hline $\begin{array}{l}\text { County } \\
\text { Prince George }\end{array}$ & 24.15 & 28.36 & 29.60 & 33.46 \\
\hline County & 13.68 & 10.23 & 13.32 & 6.38 \\
\hline Arlington County & 9.19 & 8.03 & 7.26 & 6.36 \\
\hline Fairfax County & 25.47 & 30.88 & 29.44 & 36.16 \\
\hline $\begin{array}{l}\text { Alexandria County } \\
\text { Prince William }\end{array}$ & 5.78 & 4.07 & 5.27 & 3.19 \\
\hline County & 9.03 & 8.39 & 5.11 & 3.41 \\
\hline
\end{tabular}


Appendix 1. Multinomial Logit Model Results on Location Choice in the Washington D.C. Metropolitan Area, 2000

\begin{tabular}{|c|c|c|c|c|c|c|c|c|c|c|c|c|c|}
\hline \multirow{2}{*}{\multicolumn{2}{|c|}{$\begin{array}{c}\text { Location Choice } \\
\text { (D.C. is the omitted Category) }\end{array}$}} & \multicolumn{2}{|c|}{ Montgomery } & \multicolumn{2}{|c|}{ Prince George's } & \multicolumn{2}{|c|}{ Arlington } & \multicolumn{2}{|c|}{ Alexandria } & \multicolumn{2}{|c|}{ Fairfax } & \multicolumn{2}{|c|}{ Prince William } \\
\hline & & Coef. & $Z$ value & Coef. & $Z$ value & Coef. & $Z$ value & Coef. & $Z$ value & Coef. & $Z$ value & Coef. & $Z$ value \\
\hline \multicolumn{14}{|l|}{ Moved from - } \\
\hline & Prince George's County & $4.549 * *$ & 46.61 & $2.201^{* *}$ & 20.5 & $1.023^{* *}$ & 5.51 & $1.347^{* *}$ & 6.09 & $2.405^{* *}$ & 16.27 & $2.275^{* *}$ & 6.88 \\
\hline & Montgomery County & $2.302^{* *}$ & 22.38 & $3.899 * *$ & 44.67 & 0.407 & 1.71 & $1.268^{* *}$ & 5.72 & $2.262^{* *}$ & 15.31 & $2.505^{* *}$ & 8.43 \\
\hline & Arlington County & $1.480^{* *}$ & 7.49 & $0.602 *$ & 2.31 & $4.746 * *$ & 28.78 & $3.838^{* *}$ & 19.62 & $4.309 * *$ & 25.01 & $3.959 * *$ & 12.64 \\
\hline & Alexandria County & $1.749^{* *}$ & 6.67 & $1.457^{* *}$ & 5.4 & $3.574^{* *}$ & 15.3 & $5.858^{* *}$ & 26.61 & $5.069 * *$ & 23.43 & $5.199 * *$ & 16.23 \\
\hline & Fairfax County & $1.620^{* *}$ & 11.28 & $0.827^{* *}$ & 4.54 & $3.037 * *$ & 21.39 & $3.738^{* *}$ & 23.63 & $5.928^{* *}$ & 44.56 & $5.797^{* *}$ & 23.23 \\
\hline & Prince William County & $1.825^{* *}$ & 4.4 & $2.197^{* *}$ & 5.84 & $2.930 * *$ & 7.73 & $4.063^{* *}$ & 11.42 & $5.386^{* *}$ & 17.52 & $9.114^{* *}$ & 25.35 \\
\hline & Other parts of the US & $2.171^{* *}$ & 27.95 & $1.934^{* *}$ & 26.3 & $1.604^{* *}$ & 15.15 & $2.199 * *$ & 16.94 & $3.413^{* *}$ & 31.91 & $4.574^{* *}$ & 19.63 \\
\hline \multirow[t]{2}{*}{ Education - } & Less than high school & $-0.446 * *$ & -4.29 & $0.203 *$ & 2.01 & $-0.635^{* *}$ & -4.68 & $-0.807^{* *}$ & -5.4 & $-0.523 * *$ & -4.84 & $0.452 * *$ & 3.15 \\
\hline & High school diploma & 0.064 & 1.06 & $0.640^{* *}$ & 10.2 & $-0.344 * *$ & -4.15 & $-0.257 * *$ & -2.97 & $0.272^{* *}$ & 4.53 & $1.196 * *$ & 15.65 \\
\hline \multirow[t]{4}{*}{ Age Cohort - } & $25-34$ & $0.323^{* *}$ & 3.41 & -0.157 & -1.68 & -0.032 & -0.3 & $0.306^{* *}$ & 2.61 & $0.172^{*}$ & 1.96 & 0.182 & 1.52 \\
\hline & $35-44$ & $0.698^{* *}$ & 6.91 & 0.124 & 1.24 & 0.165 & 1.43 & $0.401^{* *}$ & 3.1 & $0.550 * *$ & 5.74 & $0.420 * *$ & 3.23 \\
\hline & $45-54$ & $0.583^{* *}$ & 5.38 & -0.002 & -0.02 & 0.093 & 0.73 & $0.580 * *$ & 4.26 & $0.595^{* *}$ & 5.77 & $0.492^{* *}$ & 3.52 \\
\hline & $55-64$ & $0.436 * *$ & 3.39 & -0.04 & -0.31 & 0.183 & 1.19 & $0.477^{* *}$ & 2.84 & $0.486 * *$ & 3.84 & 0.272 & 1.58 \\
\hline \multirow[t]{2}{*}{ Marital Status - } & ingle male head & $-0.880 * *$ & -12.06 & $-0.835^{* *}$ & -10.9 & $-0.179 *$ & -1.99 & $-0.469 * *$ & -4.94 & $-0.792 * *$ & -11.04 & $-1.186 * *$ & -12.17 \\
\hline & Single female head & $-0.708 * *$ & -10.76 & $-0.841 * *$ & -12.31 & $-0.175^{*}$ & -2 & $-0.352 * *$ & -3.92 & $-0.742 * *$ & -11.11 & $-1.332 * *$ & -14.92 \\
\hline \multicolumn{2}{|c|}{ Number of Children } & $0.263^{* *}$ & 9.98 & $0.208^{* *}$ & 7.76 & -0.019 & -0.45 & $-0.153^{* *}$ & -3.39 & $0.315^{* *}$ & 11.33 & $0.390 * *$ & 11.54 \\
\hline \multirow[t]{3}{*}{ Income - } & Wages & $0.010^{* *}$ & 9.56 & $0.009 * *$ & 6.91 & $0.014^{* *}$ & 8.45 & $0.009 * *$ & 6.75 & $0.016^{* *}$ & 12.81 & $0.006^{* *}$ & 3.77 \\
\hline & Wages squared & $0.000^{* *}$ & -8.8 & $0.000^{* *}$ & -7.18 & $0.000 * *$ & -6.05 & $0.000 * *$ & -5.21 & $0.000 * *$ & -10.29 & $0.000^{* *}$ & -5.18 \\
\hline & Investment & $-0.005^{* *}$ & -3.51 & $-0.019 * *$ & -6.29 & $-0.004 *$ & -2.16 & -0.002 & -1.14 & $-0.007 * *$ & -4.9 & $-0.017^{* *}$ & -4.82 \\
\hline
\end{tabular}




\begin{tabular}{|c|c|c|c|c|c|c|c|c|c|c|c|c|c|}
\hline & Other & 0 & 0.25 & -0.002 & -1.38 & 0 & 0.22 & 0.001 & 0.46 & -0.001 & -0.82 & $-0.007 * *$ & -3.39 \\
\hline \multicolumn{2}{|l|}{ Homeowner } & $0.556 * *$ & 9.26 & $0.791^{* *}$ & 12.75 & $-0.526 * *$ & -6.43 & $-0.435^{* *}$ & -5.17 & $0.512^{* *}$ & 8.47 & $1.146 * *$ & 14.73 \\
\hline \multirow[t]{5}{*}{ Racial/Ethnic Group - } & Black & $-0.672 * *$ & -10.49 & $0.895^{* *}$ & 14.35 & $-1.470 * *$ & -14.28 & $-0.648^{* *}$ & -7.14 & $-1.176 * *$ & -16.54 & $-0.599 * *$ & -6.8 \\
\hline & Latino & -0.218 & -1.3 & $0.405 *$ & 2.35 & -0.094 & -0.48 & -0.184 & -0.84 & -0.133 & -0.86 & -0.081 & -0.42 \\
\hline & Asian & -0.125 & -0.64 & $-0.536 *$ & -2.07 & 0.392 & 1.94 & -0.528 & -1.89 & -0.049 & -0.26 & $-0.888 * *$ & -2.96 \\
\hline & Latino immigrant & -0.155 & -0.69 & 0.029 & 0.12 & 0.095 & 0.35 & 0.285 & 0.95 & -0.22 & -1 & 0.206 & 0.7 \\
\hline & Asian immigrant & 0.436 & 1.68 & $0.991 * *$ & 3.08 & -0.158 & -0.54 & 0.647 & 1.8 & $0.530^{*}$ & 2.1 & $1.171^{* *}$ & 2.97 \\
\hline \multicolumn{14}{|c|}{ Immigrant (omitted category migrated } \\
\hline \multicolumn{2}{|c|}{$\begin{array}{l}\text { Less } 5 \text { years ago) } \\
\text { L }\end{array}$} & $0.578^{*}$ & 2.39 & -0.021 & -0.08 & 0.46 & 1.55 & 0.117 & 0.36 & 0.45 & 1.73 & -0.742 & -1.87 \\
\hline \multicolumn{2}{|c|}{ Migrated to US 5-10 years ago } & 0.493 & 1.94 & 0.376 & 1.41 & 0.101 & 0.33 & 0.485 & 1.44 & 0.316 & 1.16 & 0.335 & 0.83 \\
\hline \multicolumn{2}{|c|}{ Migrated to US $10-15$ years ago } & 0.423 & 1.63 & 0.342 & 1.27 & 0.372 & 1.21 & 0.435 & 1.27 & 0.322 & 1.16 & 0.396 & 0.97 \\
\hline \multicolumn{2}{|c|}{ Migrated to US $15-20$ years ago } & 0.035 & 0.13 & 0.191 & 0.67 & -0.496 & -1.48 & 0.28 & 0.78 & 0.055 & 0.19 & 0.012 & 0.03 \\
\hline \multicolumn{2}{|c|}{ Migrated to US $20-30$ years ago } & -0.17 & -0.62 & -0.121 & -0.42 & -0.165 & -0.49 & -0.231 & -0.62 & -0.233 & -0.8 & -0.302 & -0.68 \\
\hline \multicolumn{2}{|c|}{ Migrated to US $30+$ years ago } & 0.085 & 0.26 & -0.289 & -0.79 & 0.026 & 0.06 & 0.107 & 0.23 & -0.218 & -0.61 & $1.017^{*}$ & 2.15 \\
\hline \multicolumn{2}{|l|}{ Constant term } & $-2.612^{* *}$ & -18.73 & $-2.800 * *$ & -20.43 & $-2.544^{* *}$ & -14.32 & $-3.255^{* *}$ & -16.25 & $-3.727 * *$ & -24.28 & $-5.547^{* *}$ & -20.32 \\
\hline
\end{tabular}




\section{REFERENCES}

Apgar, William, and Henry Pollakowski, "Housing Mobility and Choice," Working Paper W866, Joint Center for Housing Studies, Harvard University, Cambridge, 1986.

Boustan, Leah Platt and Robert Margo. "Job Decentralization and Postwar Suburbanization: Evidence from State Capitals". Brookings-Wharton Papers on Urban Affairs, 2009.

Gabriel, Stuart and Gary Painter, "Paths to Homeownership: An Analysis of the Residential Location and Homeownership Choices of Black Households" Journal of Real Estate Finance and Economics, Volume 27, Issue 1, 2003.

Gabriel, Stuart and Gary Painter "Mobility, Residential Location, and the American Dream: The Intra-metropolitan Geography of Minority Homeownership", Real Estate Economics, vol 36, issue 3 (2009), pp. 499-531.

Gabriel, Stuart and Stuart Rosenthal, "Household Location and Race: Estimates of a Multinomial Logit Model”, The Review of Economics and Statistics, vol. 71, no. 2 (May 1989), 240-249.

Galster, George, "Residential Segregation and Interracial Economic Disparities: A SimultaneousEquations Approach," Journal of Urban Economics 21 (1987), 22-44. 
Holzer, Harry, "The Spatial Mismatch Hypothesis: What Has the Evidence Shown?" Urban Studies, 1991, 28:105-122.

Kain, John, "Housing Segregation, Negro Employment, and Metropolitan Decentralization," Quarterly Journal of Economics 82 (May 1968), 175-197.

_ , "Black Suburbanization in the Eighties: A New Beginning or a False Hope?" paper presented at a conference entitled The Agenda for Metropolitan America; University of California, Berkeley, Sept. 1984.

Orfield, Gary and Chungmei Lee. 2005. Why segregation matters: poverty and educational inequality. Cambridge, Mass: Civil Rights Project (Harvard University).

Streitwieser, Mary, and John L. Goodman, "A Survey of Recent Research on Race and Residential Location," Population Research and Policy Review 2 (1983), 253-283. 